DOI https://doi.org/10.36059/978-966-397-160-5/1-17

\title{
BRITISH NOVEL SINCE 2000S: RETHINKING OF POST-POSTMODERN IDENTITY AND ITS ANTHROPOLOGICAL PARAMETERS
}

\section{Dmytro Drozdovskyi}

\section{INTRODUCTION}

"The Contemporary British Novel Since 2000" published in 2017 by Edinburgh University Press provides the views of British researchers on the novel of the post-postmodern period. This edition in a concise way represents the views of British theorists about the nature of the contemporary novel discussing 18 authors.

An overview of two key authors featured in this research opens the Edinburgh UP compendium: Ian McEwan and David Mitchell are characterized as the most prominent representatives of new literature whose works have new features compared to postmodern ones. The concept of "post-postmodern novelist" occurs in the compendium in the context of D. Mitchell's works. The authors of theoretical articles about eighteen writers of the contemporary literary process in the UK are bypassing the definition of post-postmodernism. However, there is also a point to say that the theoretical visions offered by researchers are not complete. For example, the article on I. McEwan's novels mentions works written after 2000, and the analysis starts with "Atonement." The key interpretative vector of the paper written by David Punter relates to the concept of lies and deception. "In Atonement Briony Tallis misconstrues the situation. She may do so by mistake; she may do so from a version of sibling rivalry; she may do so out of a sense of melodramatic self-aggrandisement; she may do so because of her self-perceived requirements as a budding writer of fiction" Acheson 2017: 18). Besides, I cannot agree that this aspect is crucial in "Saturday." After all, in the aspect of D. Punter's article, in "Atonement," the motive of misinterpretation (deception) is also be considered in the context of the idea of the multiplicity of the reality of post-postmodernism, or at least in the aspect of the alternative history, which is created as a fictitious narrative.

1 The contemporary British novel since 2000; edited by James Acheson. Edinburgh: Edinburgh University Press, 2017. 214 p. 
An analysis of the novel "Saturday" mentions the literary image of antiIraq demonstrations and the anti-militaristic motive, but in my opinion, it is also not decisive in understanding the features of McEwan's writing. D. Punter correctly draws attention to the particular precision, the composure of I. McEwan in the depiction of details, because such a detailed description, as during the car accident, is not what we often encounter in the novels. "I have not elsewhere come across such a detailed account of a minor traffic accident (apart from in legal situations, to which we shall return in The Children Act), but then such incidents have gained a specifically twenty0first-century inflection with the rise of that peculiar form of property-based violence we choose to 'road rage'. But this is not the point: the point is again a threat $\langle\ldots\rangle$ of a clash between order and chaos" (Acheson 2017: 20). D. Punter elaborates on this feature, but does not consider I. McEwan's novel in the context of ideas of new realism or postrealism.

The compendium has a separate section "Part II. Realism and Beyond", which outlines the novels of Maggie O'Farrell, Sarah Hall, A.L. Kennedy and Alan Warner. I understand and agree that postmodern irony plays a significant role in I. McEwan's novels, which undermines the seriousness of the narrative, but at the same time, it would be incorrect to reduce the interpretative dominance to an ironic modus that has a postmodern nature. I. McEwan's novels raise the question of the identity of a person who has a sick (disabled) body, the necessity (and incapacity) to understand in what aspects the issue of human evolution and brain formation has not been clarified (in the contemporary sciences) resulting in the emergence of consciousness. The interaction of the scientific and humanistic aspects defines I. McEwan's epistemological center of his novelistic writings. The analyzed compendium may be an introduction to the discussion about the theory of the contemporary British novel, but it does not reflect a significant number of trends and motives, nor does it reveal the completeness of the concepts that, according to the authors, determine the key points of the authors presented in the work.

However, in the section on D. Mitchell, the term "global novelist" is used in the title, but in the novels of the British author, it is not related only the sociopolitical context that arises in connection with this concept. "...the novel ("Cloud Atlas" - D.D.) seems to suggest that what survives a second Fall is not science (all those abandoned telescopes at the summit of Mauna Kea) but the act of narration. This kind of affirmation distinguishes Mitchell's fiction from traditional postmodern narrative. As Kathryn Simpson writes on number9dream, 'the narrative works with and through 
the postmodern towards something meaningful - repeatedly plural, ambiguous, contingent and uncertain" (Acheson 2017: 31). This definition can be used to describe "Cloud Atlas" as a narration of "something meaningful".

For example, Brian Finney giving an overview of the novels of the writer draws attention to the strengthening of the metaphysical/supernatural line in the novels "The Bone Clocks" (2014) and "Slade House" (2015), which is already representative in the novel "Cloud Atlas." Not only the idea of characters and events that lack temporality, location, etc., but also a specific ontology of time, an attempt to present an interpretation of philosophical concepts such as the Nietzsche's concept of the will to power, which in the novel is an attribute not only of the world of people but of a matter in general. B. Finney mentions this concept in his article, but misses another important Nietzsche's concept of eternal return and the necessity to reevaluate all values. In other later works, the British researcher pays attention to the metaphysics, the searches for the supernatural, and metaphysical: "His fusion of natural and supernatural is of a piece with his fusion of the personal and the global, of a waking world and the dream world, and of the realist or historical and the fictional) (Acheson 2017: 33). I assume that one of the impetus for this is the Buddhist worldview, which is represented in the works of D. Mitchell ("Cloud Atlas", "The Thousand Autumns of Jacob de Zoet"). B. Finney draws attention to D. Mitchell's master degree thesis in which the writer analyzed postmodernism. However, experiments by the British author in works ranging from the novel "Cloud Atlas" are, in B. Finney's view, not postmodern, but rather indicative of a new trend in literature. Here the British researcher agrees with the views of F. Jameson presented in the work "Antinomies of Realism."

Analyzing the specifics of the novel "Ghostwritten" (a work written in 1999) by D. Mitchell, which is quite important to outline the tendencies of the transition of postmodernism to post-postmodernism, the researchers at the same time miss a similar analysis in the section on I. McEwan, although the novel "Amsterdam." It would also be appropriate to include this novel in the discussion about post-postmodernism, because it represents several motives that are developed in the novel "Saturday" (the motive of the extremities of life and reflection on life after death, motives aging, etc.). At the same time, it is important to note B. Finney's assertion that "Mitchell's talent lies in the ability to infuse the fantastic with deep feeling" (Acheson 2017: 33). This thesis is in general confirms our concept of postpostmodernism, in the context of which the psychology of reality is actualized. Alan Riach concludes his paper with an important thesis that 
gives a clue to understand the dynamics of transformation from the postmodern to post-postmodern reality: "Does this suggest something beyond whatever might have been described as postmodernism? Perhaps no labels are needed to see that there is a moving on from the mere rejection or abandonment of 'grand narratives' as unquestionably reliable. After the contest of old socialism and new capitalism (in British terms, the decline of the triumph of Blair, known so well now as the child of Thatcher), there is, it would appear, a return to fundamental realities. In fiction, this requires more than realism and something less defined or easily categorized as allegory or symbolism" (Acheson 2017: 94). This turn to the "fundamental realities" is linked to understanding the characters' life through new allegories and symbols represented e.g. in "Cloud Atlas" (the title of the novel is a symbol and the motive of seeking for the "Cloud Atlas" sextet is an allegory).

\section{Postmodernism: Uncertain Reasons for Ambiguous Definitions}

The crystallization of postmodern ideas in the writings of its key theorists (Lyotard, Barthes, and Jameson) has provided a much better understanding of modernism. Understanding modernism through the crystallization of major concepts in postmodernism seems a natural process determined by the fact that each new cultural and historical era does not emerge from a vacuum. V. Chernetsky cites a number of American studies that, according to the researcher, attest to the "coherent understanding and 'hardening' of concepts of modernism and modernity" (Chernetsky 2008: 240), which "became possible only in the postmodern era" (Chernetsky 2008: 240). Even if postmodernism was the objection of modernism, its antithesis, over time, it was important to intensify not so much the differences as what, in fact, must be denied.

V. Chernetsky focuses in his paper on the reception of F. Jameson's ideas and writings in the post-Soviet world. The leading theorist of postmodernism (Jameson) today is considered one of the first analysts of the period to replace postmodernism. It is important that the researcher (I mean Jameson again) does not want to preserve his own theory of postmodernism, which is one of the key on the map of world theory of postmodernism, but he goes further in understanding of literary and cultural phenomena (literary and film texts). Perhaps, after Jeffrey Nealon, F. ${ }^{2}$ Jameson's work ("Antinomies of Realism") can be considered as one of the most significant in terms of the development of postmodernism. For the Anglo-Saxon paradigm of the theory of literature, the concept of "post-postmodernism" is

\footnotetext{
${ }^{2}$ Nealon J. (2012). Post-Postmodernism: Or, the Cultural Logic of Just-in-Time Capitalism. Stanford: Stanford University Press. 241 p.
} 
not common. Of course, there are several reasons for this: 1) the semantic vagueness of the term; 2) the uncertainty of post-postmodernism in the aspect of its definition: is it an era, a trend, a movement, or a particular worldview? I guess it is reasonable to discuss all the vectors of this concept. Nevertheless, F. Jameson's work "Antinomies of Realism" concludes with an analysis of D. Mitchell's "Cloud Atlas" considering this text as a prologue to a new cultural situation that is replacing postmodernism.

The issue of post-postmodernism will be presented as a separate panel discussion on «Postmodernism and After: A Literary, Cultural and Theoretical Response to Postmodernism" at the 15th ESSE (European Association of English Studies) conference to be held in Lyon in late August - early September $2020^{3}$. The organizers of this discussion are Romanian scholar Dan Horatio Popescu (Partium Christian University) and Slovakian scholar Jaroslav Kushnir (University of Prešov). The notion of "post-postmodernism" is not mentioned in the prospect but a formula acceptable in the British theory of literature is used: "Postmodernism and Beyond/After».

The latest F. Jameson's works are the following: "A Singular Modernity: Essay on the Ontology of the Present" (2002); "Archaeologies of the Future: The Desire Called Utopia and Other Science Fictions" (2005), and "Antinomies of Realism." D. Mitchell's "Cloud Atlas" expropriates as one of the key determinants of conflict in the novel the idea of overproduction (and the excessive hypertrophied consumerism): starting with goods and ending with ads (simulacra images). The production of simulacra over time becomes so intense that it subjugates all other systems affecting them in a crucial way. "Cloud Atlas" is a novel that, in essence, visibly adopted the trends that Jameson observed in his writings of the 1980s and 1990s discussing the logic of late capitalism and postmodernism. Literature, like the sphere of advertising (media), is served first, in the language; second, it is a language that replaces reality (we do not discuss the question about the intensive aspects of substitution). The works of art offer certain images created by the writers. These images may come close to reality, but they never will be the reality absolute equivalents. Advertising offers numerous pictures of people and places that seem perfect, but in reality, it is impossible to come across such an ideal, as P. Barry points out. "For example, idealized images of men and women in advertising can also be useful, since these are also copies or images without originals, because no real person is so ideal. In

$315^{\text {th }}$ ESSE-conference-2020 (Lion). List of seminars. Available at: file:///C:/Users/\% D0\%9F\%D0\%BE\%D0\%BB\%D1\%8C\%D0\%B7\%D0\%BE\%D0\%B2\%D0\%B0\%D1\%82\%D0 $\% \mathrm{~B} 5 \% \mathrm{D} 0 \% \mathrm{BB} \% \mathrm{D} 1 \% 8 \mathrm{C} /$ Downloads/ESSE2020-ListSeminars-v19SEP2019.pdf 
this way, the sign tends to become reality and together they become indistinguishable" (Barry 2008: 108). P. Barry's concludes: "Further, if we agree that the real has been lost, we must decide how to respond to that fact" (Barry 2008: 108).

\section{2. "Cloud Atlas": Post-postmodern Turn Against Simulacra Towards Meanings}

In D. Mitchell's "Cloud Atlas", the narrator demonstrates how over a long historical period reality is replaced by images. Perhaps, in understanding this phenomenon, Jameson's thesis is that "the Lacan's Real may be correlated to History" " can help us. However, D. Mitchell offers a different vision of the "Real-Imagined-Symbolic" triad and in his interpretation "History" approaches the "Imagined" as it emerges as a construct marked by the influence of ideology. Symbolically, in the novel, the entire history of mankind appears in both meanings: as a stream of clouds passing from the past to the present; and as a musical sextet that is a code and communication in the rope of events that take place in the novel in a potentially unlimited chronological aspect. Events in civilization history can be replaced by images that are of simulacrum nature but the "history of the cloud atlas" is not amenable to such substitution by simulacrum. Another way to resist the transformation of History from the Real to the Imagined is to produce personal narratives that form a memory of real events, and this form of memory matters more in terms of autonomy of human resources and independence.

"Cloud Atlas" is a novel that exemplified theoretical predictions and, if appropriate, F. Jameson's vision. The work has a distinct environmentalist pathos: it is about predicting the negative impact of technology. The starting point of this influence is conditional: no doubt, the temporal boundaries of the work could be extended, for example, to the beginning of the era of the great geographical discoveries of Christopher Columbus, which became an important (if not fundamental) milestone in the formation of politics of aggression, in the novel represented in the forms of capitalism. The geographical boundaries of the country become conditional because due to the powerful army it is possible to acquire other lands and to expand the territory of extraction of minerals and other goods. At the same time, human resources become the object of scrutiny: the institutions of power that substitute the state ideology are transformed into institutions of social control.

\footnotetext{
${ }^{4}$ Quoted from Chernetsky, p. 247, the original statement suggested by Jameson F. The Ideologies of Theory, vol. 1. Minneapolis: University of Minnesota P., 1988, P. 10.
} 
D. Mitchell's novel seems significant in terms of defining the worldview parameters of the new era for another reason: the novel expresses a clear critique of the establishment of singular meaning: neither Adam Hughes, Louise Ray, nor Sonmy 451 know in detail that their activities are parts of a major project, which is appropriate to characterize as a war against consumer ideology that is a fundamental factor in capitalism. Ideology aims to create a well-established view of the meanings. Media in the Cavendish story shapes certain boundaries in the perception of the book as a product of culture. In the fourth narrative, the book should be a tool for forming a certain cultural establishment, which over time distances itself from the idea of the author as the creator of content and meanings, who is able to inspire readers to comprehend their own lives and ask existential questions. Such questions are a factor in opening up new possibilities for the interpretation of reality, and, therefore, are dangerous to an ideology that implicitly defines the limits of interpretation. The space of excessive consumerism in the imagined future is the result of such a policy of meaning production in the society: the entertainment industry emerges as a positive vector and is perceived as socially positive (due to the implementation of such a vision in the general policy of the neo-empire). Although Neo-Seoul for the contemporary reader in the UK is undoubtedly associated with North Korea's policy, this image is also a representation of a military doctrine. One of the elements of politics in the empire was the disposition of the institutions of power, which provided subjugation (slavery). In fact, shipping and geographical discoveries (resources, etc.) have become a form of empire-building but of a new type: formally, it is a matter of extending the boundaries of communication at the interstate level but implicitly it may be about building a neo-imperialist policy and at the same time forming neocolonialism.

D. Mitchell, who exploits the entirely new principle of the compositional organization of the novel, about which F. Jameson writes in "Antinomies of Realism", forms a new vision of time as an ontological parameter of matter having

a) ontological determinism, that is a higher pattern of unfolding the world with a sense that human beings can perceive and produce;

b) the future is capable of changing the perception of the past.

F. Jameson analyzes "Cloud Atlas" as a text that represents a new literary situation. His analysis demonstrates that the literary landscape is changing, and the leading postmodern theorist is ready for new challenges from the perspective of post-postmodernism. He does not use this concept like most British theorists and historians of contemporary literature (except for Bran 
$\mathrm{Nicol}^{5}$, who follows J. Nealon's post-postmodern theory and some other scholars) but explains that the formal level of narrative organization in "Cloud Atlas" is not postmodern. I state that Jameson's interpretation of the novel resembles a kind of nostalgia for postmodernism. However, the nature of such nostalgia is quite specific: it is not about longing for postmodernism or for its own theoretical constructs: crystallization of postmodernism was in fact an attempt to look beyond postmodernism, at least by Barthes, Foucault, etc. F. Jameson exploring modernism and postmodernism predicted the possible result of the transformations and hybridizations of these cultural epochs that we observe in "Cloud Atlas." Moreover, the term "postpostmodernism" has not been mentioned in the compendium "The Routledge Companion to Twenty-First Century Literary Fiction.", Undoubtedly, it is difficult and methodologically risky to unite contemporary novels in one literary trend. Consequently, the concept of "post-postmodernism", without regard to the philosophical and poetic parameters of the recent novels, does not seem to have the potential power to unite the various works that represent the contemporary literary process of the UK.

One of the important parameters of post-postmodern thinking is historicism, which in the discourse of post-postmodernism is contaminated with the scientific and technological discourse and determined by discoveries in the field of astrophysics and biochemistry, Buddhism and supernatural. In I. McEwan's "Saturday", the protagonist Henry Perowne questions global terrorism. However, the character perceives terrorism not only in political categories as a phenomenon of planetary threat, but also as a neurosurgeon seeking to analyze the nature of terrorist actions from the standpoint of biology and biochemistry. Thus, the social phenomenon that has become the dangerous threat of the new era is finding a new interpretation in I. McEwan's novel. The nature of the criminal mind who attacks Henry is interpreted in the aspect of medicine.

D. Mitchell's "Cloud Atlas" explains historicism subordinated to the category of "timeless reality" (Acheson 2017: 88). Time in the novel exists in the categories of both ontology and anthropocene, which gives reason to discuss the representation of time in the novel in the interpretative model of both chronos and kairos. Socio-political problems related to the discourse of power, violence, non-freedom, in D. Mitchell's novel find their hypothetical

\footnotetext{
5 Nicol B. (2009). The Cambridge Introduction to Postmodern Fiction. Cambridge: Cambridge University Press. 240 p.

${ }^{6}$ The Routledge companion to twenty-first century literary fiction; edited by Daniel O'Gorman and Robert Eaglestone. London-New York: Routledge, 2018. 474 p.
} 
justification through an analysis of the nature of human relations that are subordinated to the will to power theory (F. Nietzsche). The will to power in the novel is portrayed as a universal immanent feature of human civilization. At the same time, the novel is characterized by experimentation with narrative techniques. Six narrative stories represent time as a chronos in the forms of time as a kairos (personalized). Within each narrative, there are interpolations in the form of fragments of letters, diaries, which create an idea of the representation in the novel of a real content.

\section{Autism and Post-postmodernism: New Concept for the Other}

In the novels that represent this new post-postmodern turn, medical problems are outlined, mental experiments are described, and the human individual is considered in psychological and medical aspects and so on.

Characters with Asperger's or Savant's syndrome are emerging heroes of the post-postmodern culture, and in particular of the British novel since 2000. For them, mathematics is the ideal language that makes it possible to understand the meanings lacking in the familiar communicativeanthropological world around the character. The image of autism as the Other expands the anthropological parameters of the contemporary literary studies. On the one hand, such a character has a violation in communication: if you do not follow certain rules, Christopher in Mark Haddon's "The Curious Incident of the Dog in the Night-Time" can cause an attack of rage, aggression, panic attack, and shouting. On the other hand, autism, as demonstrated in contemporary cultural texts, has particular stress resistance in difficult situations (when someone becomes ill and needs to make urgent life-saving decisions.) Autists are inquisitive and do not understand the intricacies of society created by the desire of people to flatter leadership, weave intrigues to advance the career ladder, and so on. Christopher reads mathematical manuals and imposes the concept of prime numbers represented in the work of Mark Haddon as a category of identity.

The imagery of autistic characters as a component of the anthroposphere of the contemporary British literary process, in particular, has not yet been discussed and is not inscribed in the panoramic representation of the British novel since 2000. In the compendia like The contemporary British novel since 2000 (2017); The Routledge companion to twenty-first century literary fiction (2018-2019), the category of the Other as sick/disabled person is not outlined.

This, the image of autistic characters in literature and cinematography expands an idea of the new typology of the concept of the "Otherness" (the "Other" as ill/disabled). Autists live in a world of their own mind, which is 
an important factor of their self-development. Sean in "The Good Doctor" does not accept intrigue in the medical team but it is important for him to prove to the head of the department that he has a right to be a member of the surgical department, rather than work in the department of biochemical analysis where you do not communicate to other people. The same applies, for example, to Christopher in "The Curious Incident of the Dog in the Night-Time": he gets an A + for the math exam, which indicates the character's willingness to reach to the professional goal (getting this professional success is a part of his identity represented as a prime number.) Christopher and Sean are the Others, but their form of perceiving the world, interacting with reality, etc. has some advantages for the post-postmodern world. They do not resort to deception, do not use useless phrases, do not falsify facts and do not manipulate data depending on the sociocommunicative context. On the contrary, Christopher and Sean are idealistic heroes endowed with the ability to transcend reality and rise above its absurdity. On the one hand, they appreciate facts. On the other hand, a knowledge of the subject of their researches enables the characters to see reality as a multidimensional phenomenon in which it is hypothetical to assume the existence of God or other phenomena that are transcendental/supernatural.

Autistic characters are endowed with the ability to have a comprehensive vision of reality and people, subtly discern nuances and make deep generalizations about the world. The problem for them is the anthropological component: I mean the intervention of uncontrollable human will, which makes it impossible to mechanize reality. Sean is astounded by the behavior of patients who resort to various manipulations and lies to shield someone or themselves by creating a fictitious medical history. However, the formula, represented in another medical film "Doctor House", - all people lie (except for the symptoms), - becomes a kind of motto of the post-postmodern mind and reality. The image of autism in literature and culture is generally perceived as a problem of life in a posttruth situation.

Autistic characters have values (they tell only the truth, do not to manipulate, etc.), and, therefore, these characters are inherent in a unit of axiological issues. What is common to autistic characters is the generalization of reality, the unwillingness to understand it as the intersection of truth and falsehood, as white and black. The characters of the novels and film texts live according to clear ideas (mind), while being aware of their otherness. They seek to prove to others and to themselves that they can communicate to the world and be useful for the society. Although this 
communication may appear biologically determined and genetically predetermined, however, the experience of coexisting with other characters, such as Christopher's father and mother, Mrs. Sheers, in "The Curious Incident of the Dog in the Night-Time" proves that a communication with not disabled characters has implicit convention features, and at times, is no easier than communication with autists.

I suppose that the representation of the autistic characters in literature and film texts is idealized, which is emphasized by contemporary researchers. However, the authors of the texts seek to demonstrate a way of thinking and experiences of autists in a way that has its philosophy, which, although it appears to be a black box, is not just a black box. Just there is no proper research yet to clarify the specifics of the functioning of the consciousness of such characters.

V. Frankl concludes that if "the whole meaning of life is reduced to pleasure, then as a result, we will conclude that life is devoid of meaning" (Frankl 1990: 167). The search for meaning in life (at the level of the epistemology of personal life and at the level of knowledge of universal meanings) is one of the priority themes of the contemporary British novel, in which the protagonist is a character with neuralgic disorders such as autism. The opposite strategy (excessive consumerism) leads to the tragic results and may be the determinant of the planet catastrophe.

In "The Curious Incident of the Dog in the Night-Time", Christopher's humanism is the communicative avoidance of others, a kind of instrument not to multiply lies and not to get into difficult situations in which others often demonstrate aggression and intolerance. Instead, Christopher's nonintervention strategy makes him a carrier of a new emphatic outlook: he is simply exploring himself, others around him, and the reality, to come to the heart of things and to offer new knowledge. What Christopher shares with the world can be important to parents and teachers. Who knows: maybe in 20-30 years he could propose a new theory, create a new mathematical model, or prove not-yet-solved theorem in mathematics.

In post-postmodern novels, the idea of the primordial existence of Truth (as the ontological/supernatural phenomenon) is presented. Accordingly, post-postmodern narratives actualize the motive of higher meaning that determines human life. According to V. Frankl, "it is obvious that belief in the super-sense, both in the metaphysical concept and in the religious sense of Providence, is of great psychotherapeutic and psychological importance. Like true faith based on inner strength, such faith makes a person much more viable. After all, there is nothing meaningless about such faith. $<\ldots>$. 
According to this, no drama or tragedy of a person's inner life was done intentionally" (Frankl 1990: 163).

D. Mitchell's "Cloud Atlas" is a vivid representation of such an orientation of post-postmodern discursive practices, where the motive of the existence of a super-sense or a Supreme Mind is explicit. In addition, one of the key orientations of the "Cloud Atlas" is the critique of the ideology of pleasure, which in the future leads to the creation of imitated (simulacra) reality, which ultimately makes it impossible to understand the true meanings of memory (history), institutes of power, etc. V. Frankl observed that "from our point of view, the pleasure principle is an artificial psychological construction. Satisfaction is not the goal of our aspirations, but the result of their satisfaction. $\langle\ldots>$ Schiller noted that pleasure does not emerge before us as the goal of moral action; rather, on the contrary, moral action implies pleasure. Pleasure-based theory ignores the important quality of all mental activity - intentionality" (Frankl 1990: 165). In the end, the psychologist summarizes that if "the whole meaning of life is reduced to pleasure, then as a result we will conclude that life will seem devoid of meaning" (Frankl 1990: 167). The post-postmodern meta-narrative emerges as a type of constructed reality explicating the motive for the existence of a higher reality beyond human cognition (these themes are reflected in the novels "The Curious Incident of the Dog in the Night-Time" by M. Haddon, "Cloud Atlas" by D. Mitchell, etc.).

In "Cloud Atlas," characters who know about the history of human civilization at different stages of its development seek to start the countdown from a scratch, accordingly, all that what happened in the past should be stored in the archives and become an element of the museum collection of civilization. A new type of worldview is that you need to perceive the world in an objective way avoiding forms of confrontation and not trying to change the world by building better economic or political systems. The characters of the sixth story in D. Mitchell's novel discuss the importance of obeying the laws of nature and the universe as a prototype of human relations. In nature, there is no such thing as a will (and, accordingly, a will to power, a desire for power). Each element of nature seeks to express itself in reality.

In addition, in the post-postmodern novel, the traditions of existentialism, which finds its transformed continuation in the outlook of post-postmodern characters, are exposed in a special way. The protagonists of contemporary novels are characterized by a worldview that is appropriate to characterize as existentialistic, since it arises from the awareness of one's own finiteness and inability to free your life (body and mind) from the factors that constrain death and speed and limitations of the human life. 
The representation of a person as a biochemical subject of reality enables the characters of the contemporary British novels to become aware of interaction with others through the lens of neurological abnormalities, psychophysiological disorders, biochemical imbalances. All this makes it possible to minimize your own efforts for understanding the reality. Interpersonal communication in the novel "Saturday" is determined by the protagonist's professional knowledge of human nature, of mutations in the genome that determine certain psychophysiological responses. The protagonist of the novel "The Curious Incident of the Dog in the NightTime" seeks to perceive the world through clear patterns, failures that point to certain hormonal imbalances in the human body, which in postpostmodernism is primarily regarded as a biochemical phenomenon. At the same time, such an idea of human nature imprints on the specificity of the image of consciousness, which is the determining factor of individuality. From the point of view of medicine, a person's personality can be changed because of intervention in the human brain, which can be caused by either surgery or special invasions, such as in "Cloud Atlas," where experiments on the brain become a part of a dystopian future.

Personality is no longer perceived as something unique, as a product of God, and identity is represented as a psychological component of a person with clear psychophysiological determinations. Characters who are endowed with such post-postmodern thinking in conflict situations do not seek to resolve conflicts through their own will; on the contrary, they decompose the situation into clear components, and because of the analysis of the formants of the conflicts seek to leave it without resorting to the escalation of the conflict. In this case, the conflict as a manifestation of human will in the post-postmodern narrative is a representation of the features of the biochemistry of the human body and has a clear explanation. The carrier of autistic thinking in M. Haddon's novel is endowed with precisely this vision of the world; the teenager has hypertrophied observation and is extremely attentive to the findings of others (Haddon 2004: 29). Christopher admits: “... when I really get excited about things like math or Apollo mission, books or big white sharks, I don't notice anything around me, and Father can call me for dinner, and I can't hear him. That is why I play chess so well, because I abstract my mind when needed and focus on the playing board, $<\ldots>$, and I win" (Haddon 2004: 76).

In post-postmodern novels, such as "The Curious Incident of the Dog in the Night-Time" by M. Haddon, "Carry Me Down" by M.J. Hyland, or "Cloud Atlas" by D. Mitchell, diary is the essential element of the narration on the imitation of the real life of a real person. Such a narrative model 
makes it possible to reveal the peculiarities of character communication at the level of "I-I" (Durkalevych 2015: 291) and "I-You" (Durkalevych 2015: 292). The first model reveals the immanent essence of thinking, which is inherent in stability (through the elimination of the emotional component and the desire to mechanize the world around them), the desire for unlimited cognition, curiosity and the desire to live according to the principles of truth in order to avoid false entities and multiply them in society. The second model reveals a certain "intertextual model of the reader" (Durkalevych 2015: 292); it allows to reconstruct the hypothetical recipient as "one-another" (Durkalevych 2015: 292) capable of sharing the outlook of the characters.

John in "Carry Me Down" (2006) writes the "Journal of Lies" recording all the cases of falsehood, which the character meets on his way. Such situations cause him a nausea, a psychological shock. At the same time, novels with a distinct real component also largely adopt "contextual representations with the localized communicative intentions of the text addressee" (Bekhta-Hamanchuk 2017: 3): sentences that have the impulse to arise in a problematic life situation; calamity; protest, etc.; psycho-emotional manifestations, according to $\mathrm{M}$. Bechta-Hamanchuk, presented in communicative situations ("Why did you do this? I don't even need help, and that's not his job at all!" (Hyland 2008: 58); "How can you not believe me? Why don't you want to listen to me?" (Hyland 2008: 186). Such a writing strategy reveals the emotional side of the characters. For John and Christopher crying is a protest, an automatic reaction to the violation of the world rules to be followed in communication with a character with, for example, Asperger's Syndrome. Anthropocentrism is a special way of comprehending the subject of reality, and the subject seeks to know and explicate the world and passes it through the lens of his senses. Therefore, the text reflects the qualitative evaluations of the narrator, who in the process of linguistic creative activity implements the principle of anthropocentrism" (Bekhta-Hamanchuk 2017: 9).

The study of M. Bechta-Hamanchuk proves that in the works of misery lit "narrator implements direct and indirect speech acts (representations, directives, commissions, and expressives) through all types of statements (narrative, interrogative, inciting). These speech acts are characterized by varying degrees of illocutionary power, emotional color, actualization through mental and emotional verbs, words of modal semantics and intensifiers-concretizers. Misery lit narrators discourse is dominated by representational (38\%) and expressive (31\%) speech acts. Directives (17\%) and commissions (14\%) are characterized by a lower frequency of use, but 
they have an important semantic load on the misery lit non-genre texts" (Bekhta-Hamanchuk, 2017: 16). In the pseudo-autobiographical novels "Carry Me Down" by M.J. Hyland and "The Curious Incident of the Dog in the Night-Time" by M. Haddon directives and commissions dominate, while the emotional coloring of emotional verbs is greatly reduced. In John's speech, silence is dominated by representative communicative acts, and Christopher's expressive speech acts are even more minimized.

"Why can't I look at you?"

- Because you're eleven already. You are no longer a child. $<\ldots>$

I just looked, - I say.

I want to say that there is nothing childish about looking at things, but my body is trembling under the weight of her hands, and I too tremble to speak.

- Why? - She asks. - Why do you always look at me like that? $<\ldots>$

- I do not know why. I just like it, - I say.

- Apparently, you need to get rid of this habit. <..>

"I'm sorry," I say" (Hyland 2008: 6).

\section{CONCLUSIONS}

F. Jameson's theoretical visions are considered in the aspect of their relevance for studying the specifics of post-postmodernism, in particular on the material of D. Mitchell's "Cloud Atlas", which belongs to the significant works of literature of the 21st century. The analyzed novel is one of the key in the aspect of affirmation of the thesis about the "end of postmodernism" and the need to study new literature after postmodernism in F. Jameson's "Antinomies of Realism". I proved that the attention of the American critic and theorist of culture to D. Mitchell's British novel is determined by the prognostic essence of the concept of F. Jameson, which, unlike the theories of J.-F. Lyotard, R. Barthes, and others, is not limited to postmodern narrative practices and worldviews but is rooted in the philosophical discourse of materialism, a discussion that determines the crystallization of problem-thematic units of the British post-postmodern novel. The reasons for F. Jameson's appeal to post-postmodernism are identified and the lines of poetic and philosophical dialogue between two cultural and historical periods (postmodernism and post-postmodernism) have been discussed.

In the British literary studies, today there is no integral theory of the cultural epoch that has replaced postmodernism. Representations of the simultaneous presence of the subject in several dimensions may be different and are connected with the theories of plurality of time, its nonlinear organization ("Cloud Atlas"); constructing a fictitious reality, which appears 
as a substitute for the true/real reality (the reality created by the subconscious displaces the fragments of the past) ("Curious Incident..."); the protagonist cannot reliably identify which of the realities is true, since there are no clear verification tools ("Saturday", "Atonement").

The post-postmodern novels written in the form of diaries or with the key role of notes approach a pseudo-autobiography narration in which the image of a real component is of particular epistemological and anthropological significance. Attention to the real in the discourse of the British postpostmodern novel reinforces the blurring of the boundary between the fictional (imaginary) and the present creating the effect of vitality and contributing to the immersion of the recipient into the constructed world for the sake of understanding of the Other.

Christopher in "The Curious Incident of the Dog in the Night-Time", searches for meaning in life and embraces new knowledge. A teenager with Asperger's Syndrome discovers a new philosophy of existentialism and exemplifies a new humanism, an important factor in the principle of intentionality, albeit through the tragic experience of reality at the time of apotheosis from collision with it. Instead, writers criticize the concept of life as a pleasure because such a strategy results in the substitution of true reality for a fictitious, meaningless reality, which is a simulacrum.

\section{SUMMARY}

Purpose of the paper is to identify the anthropological specifics of the contemporary British novel, one of the key units of which is the anthropological specificity of the new post-postmodern worldview. For the first time, the latest British compendia of 2017-2018s, which emphasize the philosophical and anthropological peculiarities of the contemporary British novel, have been discussed. The strategies of the functioning of the Other as an anthropological category of the present literature have been outlined, in particular, it is emphasized on the images of characters with autism. It has been proved that anthropological problems become key ones in postpostmodern discourse and determine the specifics of the development of the British novel since 2000s. The reasons for characterizing the way of thinking of characters with autism as the representatives of the new existentialism has been outlined and explained. Having analyzed the latest compendia, which systematize the theoretical approaches of British scholars in the aspect of understanding of the paradigm of the British novel since 2000, the specific representation of problem-thematic units in British novels since 2000 has been spotlighted. 


\section{REFERENCES}

1. Barry P. (2008). Vstup do teorii: literaturoznavstvo ta kulturolohiia [Introduction to Theory: Literary Studies and Cultural Studies]. Kyiv: Smoloskyp.

2. Bekhta-Hamanchuk M. P. (2017). Komunikatyvni intentsii naratora u brytanskii khudozhnii literaturi pochatku XXI st.: dys. ... kand. filol. nauk : 10.02.04. [Narrator's Communicative Intentions in British Fiction of the Beginning of the XXI century]. Zaporizhzhia: Zaporizkyi natsionalnyi universytet.

3. Chernetskyi, V. (2008). Postmodernizm chy kulturna lohika postkomunizmu? Znaiomstvo $\mathrm{z}$ Dzheimisonom [Postmodernism or the Cultural Logic of Post-communism? Introduction to Jameson]. Modernizm pislia postmodernu [Modernism after [postmodernism]. Kyiv: PTs «Foliant». 231-260.

4. Durkalevych, V. (2015). U poshukakh naratyvnoi identychnosti: indyvidualnyi mif u tvorakh Ivana Franka, Andzheia Khtsiuka i Bruno Shultsa. Drohobych: Kolo.

5. Frankl V. (1990). Chelovek v poiskakh smysla: Sbornik: obshch. red. L.Ya. Gozmana i D.A. Leontieva. Moscow: Progress.

6. Haddon M. (2004). The Curious Incident of the Dog in the NightTime. London: Vintage.

7. Hyland M. J. (2008). Uhomony menia. Lviv: Kalvaryia.

8. McEwan I. (2007). Subbota. Lviv: Kalvaryia.

9. Mitchell D. (2004). Cloud Atlas. London: Random House.

10. The contemporary British novel since 2000 (2017): edited by James Acheson. Edinburgh: Edinburgh University Press.

11. The Routledge companion to twenty-first century literary fiction (2018): edited by Daniel O'Gorman and Robert Eaglestone. London-New York: Routledge.

Information about the author: Dmytro Drozdovskyi,

$\mathrm{PhD}$, Candidate of Philological Sciences, Academic Fellow of the Department of World Literature,

T. Shevchenko Institute of Literature of the National Academy of Sciences of Ukraine 4, M. Hryshevskyi str., Kyiv, 01001, Ukraine ORCID ID: orcid.org/0000-0002-2838-6086 